\title{
The efficacy of Copper Oxide, Tri-calcium Phosphate and Silicon Dioxide Nanoparticles in Controlling Black Scurf Disease of Potato
}

\author{
Eman S.A. El-Shewy ${ }^{2}$, Mohemed, F. G. ${ }^{1}$, Faten M. Abd-latif ${ }^{1}$, Hafez E. M. ${ }^{1}$ and Mansour S. A. ${ }^{2}$ \\ ${ }^{1}$ Plant Pathology Department, Faculty of Agriculture, Banha University \\ ${ }^{2}$ Vegetable disease department, Plant Pathology Research institute, Agricultural Research Center, 12619 Giza, \\ Egypt \\ Corresponding author: memeshewy@gmail.com
}

\begin{abstract}
Black scurf disease caused by Rhizoctonia solani, was a serious and common disease on potato worldwide. Effect of nanoparticles forms of Tri-calcium phosphate, copper oxide and silicon dioxide nanoparticle was evaluated at five concentrations to control black scurf disease in vitro and in vivo. Examination of treated $R$. solani with different tested nanoparticle was done using Transmission Electron Microscope (TEM). Activities of defense related enzyme were determined in artificially inoculated potato plants and tubers (cv. Spunta) with $R$ solani. Physical characteristics of tested nanoparticles exhibit that all of them are spherical in shape and varied in their sizes. Also, all tested nanoparticles exhibited inhibitory effect of $R$. solani. Non-copper oxide was the most effective one (56.42\%) in suppressing the mycelial growth of $R$. solani at concentration $250 \mu \mathrm{l} / \mathrm{L}$. The TEM examination of treated $R$. solani with different nanoparticles exhibit that instability they caused in cell wall thickness, abnormalities of nucleus and disappearance of nuclear membrane. All tested nanoparticles reduced of incidence and severity\% of black scurf disease at concentrations 150 and $200 \mu \mathrm{l} / \mathrm{L}$. during 2014 and 2015 seasons. Results cleared also that treating potato plants with different tested nanoparticles affected positively the activities of poly phenoloxidase, peroxidase, catalase and chitinase enzymes in leaves and tubers.
\end{abstract}

Key words: Potato, Black scurf disease, Rhizoctonia solani, Nanoparticles, Transmission Electron Microscopy (TEM), defense related enzymes.

\section{Introduction}

Potato (Solanum tuberosum L.) is the fourth largest food crop worldwide after wheat, maize and rice (Kaguango et al. 2008; Haimdeldin and Hussien 2013). Potatoes play a significant role in human nutrition worldwide, where more than 320 million tons of potatoes are produced annually from 20 million hectares (Poczai et al. 2010; Sneyers 2010). Potatoes ranked after soybean for amount of protein/ha, with the major storage protein being patatin, one of the most known nutritionally balanced plant proteins (Liedl et al. 1987). About $150 \mathrm{~g}$ of potato provides up to $45 \%$ of recommended daily allowance (RDA) for vitamin C, $10 \%$ vitamin $\mathrm{B} 6,8 \%$ niacin, $6 \%$ folate and other essential mineral nutrients (Patil et al. 2016). Egypt is one of 15 countries that export unprocessed raw potatoes with shipped dollar value, US\$ 272.7 million during 2017 of (Workman, 2018).

Black scurf disease caused by Rhizoctonia solani (Telomorph: Tanatephrus cucumeris) is one of the mostimportant fungal disease attacking potato (Wilson et al. 2008; Rubayet et al. 2018). Rhizoctonia solani is wide spread fungus causing damage to many crops under wide range of temperatures from $10-24{ }^{\circ} \mathrm{C}$ (Dorrance et. al. 2003). The plant pathogen R. solani is very difficult to control due to its persistent, long living sclerotial structures in soil (Zachow et al. 2011). Agriculture has been one of the most recent disciplines to join the nanotech race (Pérez-de-Luque \& Hermosín, 2013). Several nanoparticles are being explored these days for their antimicrobial effects (Ren et al. 2009; Jia et al. 2012), which it can be beneficial or harmful, depending on the context. Nano-copper was reported to be highly effective in controlling bacterial diseases i.e. bacterial blight of rice (Xanthomonas oryzae pv. oryzae) and leaf spot of mung bean (X. campestris pv. phaseoli) (Gogoi et al. 2009). Also, copper nanoparticles (CuNP) have been reported as effective antimicrobial in several studies (Cioffi et al. 2005; Ren et al. 2009; Jia et al. 2012). At low concentration, CuNPs promoted the growth of the plant pathogenic fungi; Botrytis fabae, Fusarium oxysporum f. sp. ciceris, F. oxysporum f.sp. melonis, Alternaria alternata and Pseudomonas syringae, and sporulation of T. harzianum (Banik and Perez-de-luque 2017).On the other hand, Nano sized silica-silver at concentration $10 \mu \mathrm{l} / \mathrm{L}$ revealed $100 \%$ inhibition of mycelial growth of Pythium ultimum, Magnaporthe grisea, Colletotrichum gloeosporioides, Botrytis cinere and, Rhizoctonia solani, (Park et al. 2006). The Nano silica-treated plants showed higher expression of phenolic compounds and lower expression of stress-responsive enzymes against both fungi. 
The present study aimed to evaluate the potential effect of Tri-calcium phosphate, copper oxide and silicion dioxide nanoparticles in controlling potato black scurf disease in vitro and in vivo. Also using the TEM as a good tool for clearing the effect of tested nanoparticles in controlling $R$. solani the causal of potato black scurf.

\section{Materials and Methods}

\section{1- Isolation of potato black scurf Pathogen}

Rhizoctonia solani was isolated on potato dextrose agar (PDA) medium from diseased potato tubers exhibiting typical symptoms of black scurf disease.
Purification of the isolated fungi was done using the hyphal tip technique. The pathogen was identified as $R$. solani based on microscopic observation of morphological structures described by Sneh et al. (1991). Rhizoctonia solani was maintained on PDA in sterile disposable plastic Petri dishes at $25 \pm 2{ }^{\circ} \mathrm{C}$ for further work.

\section{2- Source of nanoparticles}

Three materials i.e, Copper oxide, Tri-calcium phosphate and Silicon dioxide were obtained in form nanoparticles from NanoTech. Egypt for PhotoElectronics (Table .1).

Table 1. List of tested nanoparticles chemical structure and characteristics

\begin{tabular}{llll}
\hline Product name & Chemical structure & Solubility & Size average (nm) \\
\hline Copper oxide & $\mathrm{CuO} \mathrm{NPs}$ & Suspended in water & Less than 100 \\
Tri-calcium phosphate & $\mathrm{Ca}_{3}\left(\mathrm{PO}_{4}\right)_{2} \mathrm{NPs}$ & Dispersed in water & Less than 50 \\
Silicon Dioxide & $\mathrm{SiO}_{2}$ NPs & Dispersed in water or ethanol & Less than 50 \\
\hline
\end{tabular}

\section{3- Physical characteristics of tested nanoparticles}

Images, crystal structure revelations and elemental analysis (qualitative and semi-quantitative analysis) were done of the three tested nanoparticales using High Resolution Transmission Electron Microscope (HRTEM, Tecnai G20, FEI, Netherland). In this respect, Two different modes of imagine were employed; the bright field at electron accelerating voltage $200 \mathrm{kV}$ using lanthanum hexaboride (LaB6) electron source gun and the diffraction pattern imaging. Eagle CCD camera with $(4 \mathrm{k} * 4 \mathrm{k})$ image resolution was used to acquire and collect transmitted electron images. TEM Imaging \& Analysis (TIA) software was used to spectrum acquisition and analysis of EDX peaks.

\section{4- Effect of tested nanoparticles on growth of $R$. solani in vitro}

Nanoparticles forms of Copper oxide, Tricalcium phosphate and Silicon dioxide were evaluated in vitro against $R$. solani at five concentrations; 50, 100, 150,200 and $250 \mu 1 / \mathrm{L}$. The tested nanoparticles were added individually to conical flasks containing sterilized PDA medium to obtain the proposed concentrations then mixed gently. before solidification, the treated medium with nanoparticles were poured into 4 sterilized Petri dishes $(9 \mathrm{~cm}$ diameter) per each treatment. After medium solidification, PDA plates were individually inoculated in the center with equal mycelial plugs (5$\mathrm{mm} \varnothing$ ) and incubated at $24 \pm 2{ }^{\circ} \mathrm{C}$ for 7 days. The inoculated PDA plates with only mycelial plugs served as control. The diameter of developed colonies was measured when fungus filled the control plate. The percentage of reduction in the colony diameter was calculated using the formula suggested by Sirirat et al. (2009) as follows:
Reduction $\%=\frac{(\mathrm{de}-\mathrm{di})}{\mathrm{de}} \times 100$

Where:

$\mathrm{De}=$ maximum linear growth in control set. $\quad \mathrm{Di}=$ maximum linear growth in treatment set.

\section{5- Examination of $R$. solani by Transmission Electron Microscopy (TEM)}

Specimens of $R$. solan $i$ that treated by copper oxide, Tri-calcium phosphate and silicon dioxide were prepared for TEM examination using the protocol of Amin, (2013).

\section{6- Efficacy of nanoparticles on black scurf disease under greenhouse conditions}

The trials were carried out during the summer season of 2014 and 2015 on potato cv. Spunta at the Experimental Greenhouse of the Vegetable Diseases Research Department, Plant Pathology Research Institute, Agricultural Research Centre, Giza, Egypt.

\subsection{Soil preparation and potato seeding:}

Soil mixture of peat-moss and sand $(2: 1 \mathrm{w} / \mathrm{w})$ was prepared and sterilized with formalin solution 5\% concentration, then covered with polyethylene sheet for 2 weeks. Later on, the cover was removed and the mixture was exposed to air ventilation for 10 days to evaporate formalin residues.

Plastic pots $(50 \mathrm{~cm}$ diameter) were sterilized by dipping in 5\% formalin solution for $15 \mathrm{~min}$. and then airdried for $24 \mathrm{hrs}$. Pots were filled with sterilized soil mixture and six pots were used as replicates for each treatment. The filled pots were inoculated by $R$. solani isolates with rate of $20 \mathrm{~g} / \mathrm{kg}$ soil and watered for 4 days 
before planting (Abd-El-Aziz et al. 2013; Mohamoud et al. 2013). Control pots were inoculated with only autoclaved sorghum-sand mixture at the same rate. The pots were then placed into greenhouse at $25 \pm 3{ }^{\circ} \mathrm{C}$.

\subsection{Inoculum preparation}

For mass multiplication, fungal cultures were grown on sterilized sorghum grain in autoclavable glass bottles as following; one kilogram of sorghum grain were soaked in water for $12 \mathrm{~h}$, soaked sorghum grain divided into five flasks $200 \mathrm{~g} /$ flask and autoclaved at $121^{\circ} \mathrm{C}$ for $20 \mathrm{~min}$. All flasks were inoculated with mycelial plug $(5 \mathrm{~mm})$ of 7 days old culture of $R$. solani. The flasks were then incubated at $25 \pm 2{ }^{\circ} \mathrm{C}$ for 2 weeks.

\subsection{Treatments}

Copper oxide, Tri-calcium phosphate and silicon dioxide nanoparticles were evaluated at four concentrations against $R$. solani under greenhouse conditions. Application of nanoparticles materials was done twice. The first application was done by soaking potato tubers in tested nanoparticles at four concentrations $(50,100,150$ and $200 \mu \mathrm{l} / \mathrm{L})$ for $2 \mathrm{hr}$. preplanting. The second application was done at 45 days post-planting as soil drench. After 90 days from planting, tubers were harvested and kept in a dry place at room temperature for two days. The tubers were then washed carefully to remove soil residues. The black scurf disease index was assessed and compared with the control of each plant. The ratio of tuber surface area covered with sclerotia was used as general method to estimate potato black scurf as the following scale (Hadi and Balali 2010 \& Matny and Al-Jarrh 2014):

0 : no sclerota present

1: less than $1 \%$ of tuber area covered

2: from $2-10 \%$ of tuber area covered

3: from $11-20 \%$ of tuber area covered

4: from $21-50 \%$ of tuber area covered

5: $51 \%$ or more of tuber area covered

Disease incidence $\%=$ No. of infected tubers $/$ total No. of inspected tubers X 100

Disease severity\%

$=\sum$ (No. of infected tubers $\times$ No. of scale $) \times 100$

(Total No. of tubers $\times$ highness No. of scale)

7. Activities of defense related enzymes:

\subsection{Enzymes extraction:}

Artificially inoculated potato plant and tuber were used to determine the activities of the oxidative enzymes. In this respect, $50 \mathrm{~g}$ from representative plants and tubers of each treatment were blended with $100 \mathrm{~mL}$ phosphate buffer solution $(7.1 \mathrm{pH})$ then centrifuged at $3000 \mathrm{rpm}$ for 20 minutes. Clear supernatants were used as crude enzyme to determine enzyme activities

\subsubsection{Peroxidase activity:}

Peroxidase activity was determined according to the method described by Allan and Hollis (1972). Peroxidase was expressed as the change in the absorbance of the mixture every 0.5 minute for 3 minutes period at $425 \mathrm{~nm}$ by Spectrophotometer (Spectronic 601 Milton ROY).

\subsubsection{Polyphenol oxidase activity:}

The activity of polyphenol oxidase was measured as mentioned by Matta and Dimond (1963). Polyphenol oxidase was expressed as the change in the absorbance of the mixture every 0.5 minute for 3 minutes period at $495 \mathrm{~nm}$ by Spectrophotometer (Spectronic 601 Milton ROY).

\subsubsection{Chitinase activity:}

Chitinase activity was assayed according to Miller (1959). Briefly, the reaction mixture composed of $1 \mathrm{~mL}$ of crude enzyme solution, plus $1 \mathrm{~mL}$ of $0.5 \%$ colloidal chitin in $0.1 \mathrm{M}$ citrate buffer ( $\mathrm{pH} 7.0)$. The mixture was then incubated at $37^{\circ} \mathrm{C}$ in a shaking water bath for 30 min. The reaction was then terminated by adding $2 \mathrm{~mL}$ DNS(Di nitro salicylic reagent) reagent. The color was developed in a boiling water bath for $5 \mathrm{~min}$. The optical densities of samples were measured at $575 \mathrm{~nm}$ against a blank containing ( $1 \mathrm{~mL}$ substrate-buffer solution $0.5 \%$, $1 \mathrm{~mL}$ buffer and $2 \mathrm{~mL}$ DNS). N-acetyl glucosamine (GLcNAc) was used as a standard. The enzyme activity was expressed as $\mu$ moles GLc NAc $\mathrm{g} / \mathrm{mL}$.

\section{Preparation of DNS reagent:}

The following components; $1 \mathrm{~g}$ of dinitrosalicylic acid, $200 \mathrm{mg}$ of crystalline phenol and $50 \mathrm{mg}$ of sodium sulphite were dissolved simultaneously in $1 \%$ solution of $\mathrm{NaOH}$. The reagent was stored in a stopper bottle at $4^{\circ} \mathrm{C}$. The reagent deteriorates during storage due to atmospheric oxidation of the sulphite present.

\subsubsection{Catalase enzyme:}

Catalase enzyme activity was determined following the method of Kato and Shimizu (1987). In the sample cuvette; $0.1 \mathrm{ml}$ of crude extract was mixed with $0.5 \mathrm{ml}$ of $0.2 \mathrm{M}$ sodium phosphate buffer at $\mathrm{pH} 7.6$ and $0.3 \mathrm{ml}$ of $0.5 \% \mathrm{H}_{2} \mathrm{O}_{2}$ then the mixture brought to a final volume of $3 \mathrm{ml}$ with distilled water. The breakdown of $\mathrm{H}_{2} \mathrm{O}_{2}$ was recorded by measuring the absorbance at $240 \mathrm{~nm}$ and the enzyme activity was calculated as the change in absorbance per minute.

\section{Results and Discussion}

\section{Examination of nanoparticle materials}

Tri-calcium phosphate, copper oxide and silicon dioxide nanoparticles were examined using Transmission Electron Microscopy (TEM) (Fig. 1A, B and C). These nanoparticles of Tri - calcium phosphate were spherical and displayed sizes, 85.2, 87.7 and 94.7 
nm (Fig. 1A). The TEM micrographs revealed that copper oxide nanoparticles were spherical in shape with size between 28.6 and $38.6 \mathrm{~nm}$ (Fig. 1B). In addition, the TEM analysis concluded that silicon dioxide particles were also spherical between 26.4 and $32.2 \mathrm{~nm}$ in size (Fig. 1C). Our results revealed that the characteristics of calcium phosphate, copper oxide and silicon dioxide nanoparticles are similar with those previously reported (Caiab and Tang, 2008; Yuvakkumar et al., 2011; Suriyaprabha et al., 2014; Prachi et al., 2014) whot stated that nano-calcium had spherical shape between $25-100 \mathrm{~nm}$ in diameter by using atomic force micrscopy (AFM) comfired by transmission electron silicon dioxide (TME) also silicon dioxide had spherical shape with dimater 20-40nm.
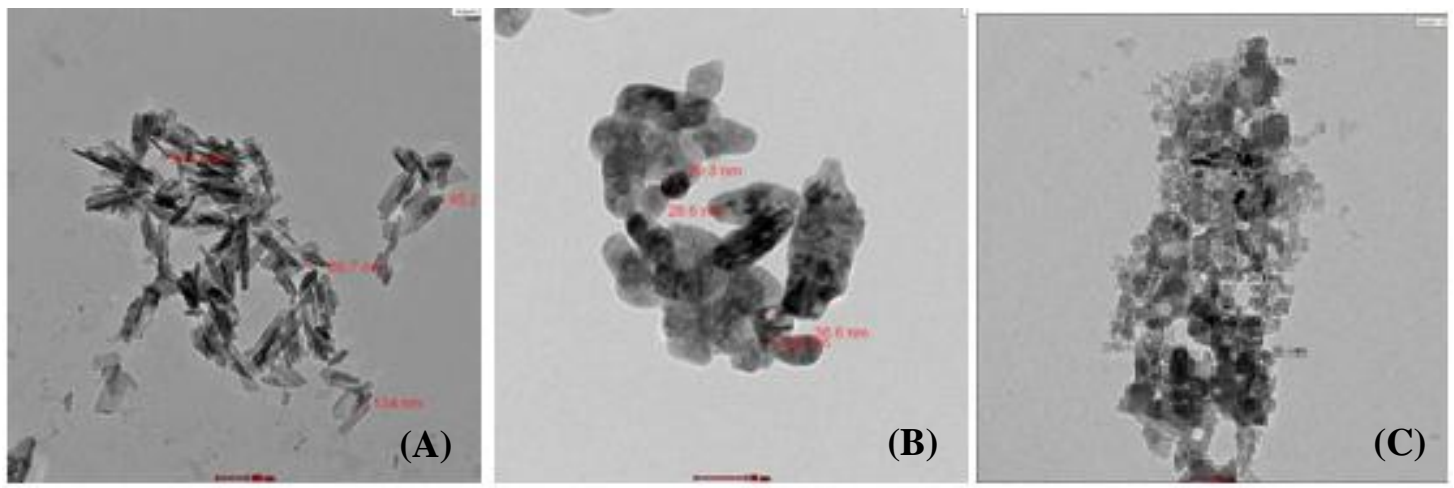

Figure. 1 TEM of nanoparticles materials used in this study; (A) nano- Tri - calcium phosphate, (B) nano - copper oxide (C) nano - silicon dioxide .

\section{Effect of tested nanoparticles on the growth of $R$. solani in vitro.}

Tri-calcium phosphate, copper oxide and silicon dioxide nanoparticles were evaluated at five concentrations for their inhibitory effect on $R$. solani. Results in Table (2) indicate that, all evaluated concentrations of nanoparticles suppressed the mycelial growth of $R$. solani in campning to control. However, copper oxide nanoparticles exhibited the highest reduction $(56.42 \%)$ of mycelial growth of $R$. solani at concentration $250 \mu \mathrm{l} / \mathrm{L}$. Similarly, silicon dioxide exhibited a clear reduction in fungal growth at $250 \mu \mathrm{l} / \mathrm{L}$ with percentage $54.81 \%$. On the other hand, silicon nanoparticles had the lowest effect on growth of $R$. solani at concentration $50 \mu \mathrm{l} / \mathrm{L}$. The obtained results coincided with those obtained by Kim et al. (2011) who stated that the mycelial growth rate of $R$. solani was decreased typically by more than $90 \%$ at a $6 \mu \mathrm{g} / \mathrm{ml}$ concentration of Nano sized silica hybrid silver complex (NSS). Similar results were obtained by Ramyadevi et al. (2012) who found that copper nanoparticles showed inhibitory activity against Micrococcus luteus, Staphylococcus aureus, Escherichia coli and Pseudomonas aeruginosa and fungi .i.e. Aspergillus flavus and Aspergillus niger, Moreover, Kanhed et al. (2014) reported that copper nanoparticles (CuNPs) showed remarkable activity against Alternaria alternata, Fusariun oxysporum, Curvularia lunata and Phoma distructiva. The enhanced antifungal activity of CuNPs was due to their large surface area to volume ratio. Bramhanwade et al. (2015) declared that copper nanoparticles exhibited significant and great activity against $F$. equiseti.

\section{TEM of treated $R$. solani that with tested nanoparticles:}

The effect of copper oxide nanoparticles on the ultrastructure of $R$. solani was shown in Figure 2 (C and D). There were clear morphological changes observed on the $R$. solani mycelium. These changes were; instability in cell wall thickens. Additionally, deformation of nucleus and disappearance nuclear membrane was also observed. This result takes the same direction obtained by Schrand et al. (2010) hypothesized that copper nanoparticles act as antibacterial agent against wide range of bacterial species due to interactions with SH-groups leading to protein denaturation. Moreover, Beveridge and Murray (1980) and Ren et al. (2009) indicated that copper nanoparticles exhibited an effect on cell membrane of $B$. subtilis due their affinity towards amines and carboxyl groups present on the cell surface. Furthermore, copper nanoparticles may bind with DNA molecules and disturb the helical structure by cross-linking within and between the nucleic acid strands. Gopalakrishnan et al. (2012) suggested the possible mechanism for mode of action of copper oxide nanoparticles against $E$. coli that nanoparticles adsorb on cell surface and interact with the cell wall causing damage to the cell membrane, increasing its permeability and leading to a decrease in 
its viability. Furthermore, Chang et al. (2012) discussed three different mechanisms based on oxidative stress, coordination and no homeostasis effects that potentially explain why copper and zinc oxide nanoparticles display toxic effects on eukaryotic cells.

Table 2. Effect of three tested nanoparticles materials at different concentrations on the growth of $R$. solani in vitro.

\begin{tabular}{llll}
\hline \multirow{2}{*}{$\begin{array}{l}\text { Concentrations } \\
\text { T1/L }\end{array}$} & \multicolumn{2}{c}{ R. solani } \\
\cline { 3 - 4 } & $\mathbf{5 0}$ & 70.20 & Mycelial growth (mm ) \\
\hline Copper oxide & $\mathbf{1 0 0}$ & 60.33 & 22.00 \\
& $\mathbf{1 5 0}$ & 50.20 & 32.97 \\
& $\mathbf{2 0 0}$ & 40.33 & 44.22 \\
& $\mathbf{2 5 0}$ & 39.23 & 55.19 \\
& $\mathbf{5 0}$ & 70.25 & 56.41 \\
& $\mathbf{1 0 0}$ & 70.28 & 21.94 \\
Tri-calcium phosphate & $\mathbf{1 5 0}$ & 57.95 & 21.92 \\
& $\mathbf{2 0 0}$ & 55.58 & 35.61 \\
& $\mathbf{2 5 0}$ & 50.53 & 38.25 \\
& $\mathbf{5 0}$ & 90.00 & 43.86 \\
Silicon dioxide & $\mathbf{1 0 0}$ & 70.60 & 0.00 \\
& $\mathbf{1 5 0}$ & 63.08 & 21.56 \\
& $\mathbf{2 0 0}$ & 50.63 & 29.92 \\
Control. & $\mathbf{2 5 0}$ & 40.68 & 43.75 \\
\hline L.S.D at 5\% & & 90.00 & 54.81 \\
& & & 0.00 \\
\hline
\end{tabular}

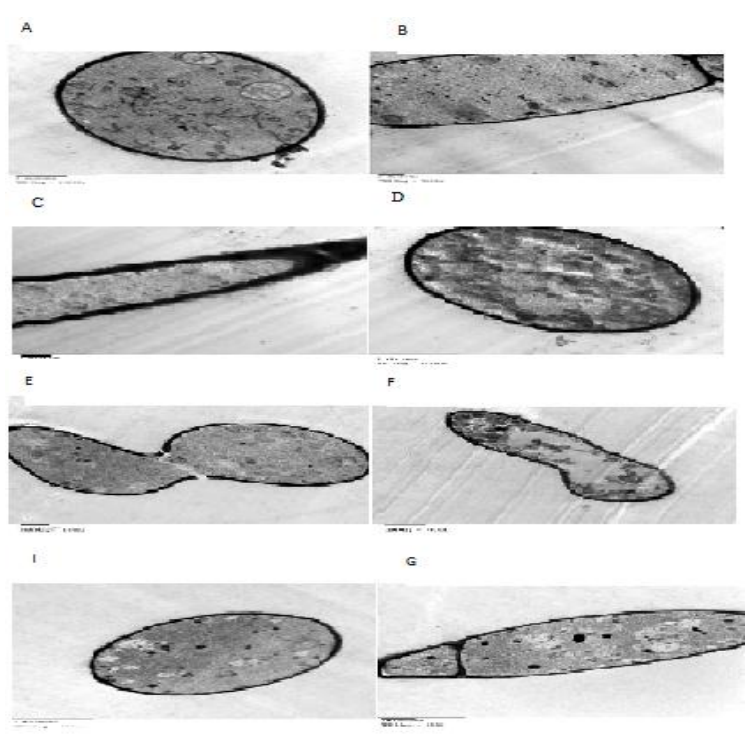

Figure. 2 TEM examination of $R$. solani hyphae; (A and $\mathrm{B}$ ) untreated (C and D) $R$. solani treated with copper oxide nanoparticles; (E and F) $R$. solani treated with Tri-Calcium phosphate nanoparticles; (I and G) $R$. solani treated with Silicon dioxide nanoparticles

On the other hand, Tri-calcium phosphate nanoparticles had many effects on the ultrastructure of $R$. solani. These effects belonged that cell wall and membrane were thickened, cell wall and cell membrane were characterized by possessing thick weak, numerous vascular were observed, deformation of ultrastructure cytoplasmic organelles, deformed shape of nucleus and disappear of septum (Fig. 2E and F) compared with the control (Fig. 2A and B).

Also, silicon dioxide nanoparticles caused irregular and deformed shape of nucleus, abnormalities of nucleus and chromatin bodies (Fig. (2)I and G). There 
are many theories explained the mechanism of silica nanoparticles against microorganisms. In this regard, the antifungal effect of silica nanoparticles may be achieved via breakdown of cell wall by forming hydrogen bonds between lipopolysaccharide-rides of the cell wall and surface hydroxyl groups present in silica nanoparticles (Capeletti et al. 2014). Also, the accumulation of silica nanoparticles in the membrane may induce cell lysis by preventing the trans-membrane energy cycle or form insoluble compounds in the fungal membrane that disrupt the electron transport chain (Gill et al. 2005). Other theory suggested that accumulation of silica nanoparticles induce oxidation of the cell membrane due to the positive charge of silica nanoparticles and the negative charge of cell membrane that produces the electromagnetic attraction between both resulting in immediate cell death (Rezaei-Zarchi et al. 2010).

\section{Effect of nanoparticle materials on black scurf in} vivo

Data in Table (3) indicate that all tested nanoparticle materials at all concentration reduced infection $\%$ and disease severity $\%$ of black scurf disease under greenhouse condition comparing with control. Also, all tested nanoparticles materials at concentration of $200 \mu \mathrm{l} / \mathrm{L}$ had reduced completely black scurf disease during seasons 2014 and 2015. Treatment with tricalcium phosphate nanoparticles at $150 \mu 1 / \mathrm{L}$ revealed a great reduction of diseases incidence and severity $\%$ nearly to Rizolex result with efficacy 80.91, 71.95\% respectively during season 2014 and with efficacy (DI) $81.82 \%$, (DS) $69.94 \%$ of season 2015. Also, silicion dioxide and copper oxide nanoparticles revealed a significant reduction in DI\% and DS\% at $150 \mu \mathrm{l} / \mathrm{L}$ during the two seasons. All treatments with nanoparticles at concentration $150 \mu \mathrm{l} / \mathrm{L}$ displayed reduction in DI\% and DS\% and efficacy with values close to the Rizolex, being calcium phosphate nanoparticles is the closest. Also, it was clear that increasing the concentration of the tested nanoparticles materials from 50 to $200 \mu \mathrm{l} / \mathrm{L}$, increased gradually their effect in reducing of DI\% and DS\% of black scurf disease.

These results are in agreement with those obtained by Brecht et al. (2004) who reported that silica nanoparticles increased resistance and stress resistance in plants. Also, Nano-copper was reported to be highly effective in controlling bacterial diseases such as bacterial blight of rice caused by Xanthomonas oryzae pv. oryzae) and leaf spot of mung bean caused by $X$. campestris pv. phaseoli (Gogoi et al., 2009). Kanhed et al. (2014) declared also that synthesized CuNPs has antifungal activity against plant pathogenic fungi. This may open up new avenues in the field of plant disease control.

Table 3. Effect of three tested nanoparticles on black scurf disease in vivo.

\begin{tabular}{|c|c|c|c|c|c|c|c|c|c|}
\hline \multirow{3}{*}{ Treatments } & \multirow{3}{*}{$\begin{array}{l}\text { Con. } \\
\mu \mathrm{l} / \mathrm{L}\end{array}$} & \multicolumn{8}{|c|}{ R. solani } \\
\hline & & \multicolumn{4}{|c|}{ Season 2014} & \multicolumn{4}{|c|}{ Season 2015} \\
\hline & & DI & Ef. & DS & Ef. & DI & Ef. & DS & Ef. \\
\hline \multirow{4}{*}{ Copper oxide } & 50 & 53.33 & 30.44 & 24.65 & 28.22 & 50.00 & 31.11 & 24.88 & 20.94 \\
\hline & 100 & 35.00 & 51.35 & 19.97 & 42.38 & 33.33 & 54.54 & 19.97 & 36.54 \\
\hline & 150 & 21.67 & 71.74 & 11.99 & 67.20 & 23.33 & 70.45 & 13.04 & 58.57 \\
\hline & 200 & 0.00 & 100.00 & 0.00 & 100.00 & 0.00 & 0.00 & 0.00 & 100.00 \\
\hline \multirow{4}{*}{ Tri-calcium phosphate } & 50 & 50.00 & 34.26 & 24.04 & 20.79 & 50.00 & 31.81 & 24.71 & 21.48 \\
\hline & 100 & 26.67 & 65.00 & 21.66 & 37.51 & 26.67 & 63.63 & 19.01 & 39.59 \\
\hline & 150 & 15.00 & 80.91 & 9.55 & 71.95 & 13.33 & 81.82 & 10.09 & 69.94 \\
\hline & 200 & 0.00 & 100.00 & 0.00 & 100.00 & 0.00 & 100.00 & 0.00 & 100.00 \\
\hline \multirow{4}{*}{ Silicon dioxide } & 50 & 55.00 & 28.26 & 25.96 & 27.53 & 53.33 & 28.89 & 23.63 & 24.90 \\
\hline & 100 & 31.67 & 43.48 & 20.85 & 42.15 & 31.11 & 57.58 & 18.63 & 36.29 \\
\hline & 150 & 16.67 & 78.26 & 13.52 & 68.25 & 18.33 & 75.58 & 12.12 & 67.94 \\
\hline & 200 & 0.00 & 100.00 & 0.00 & 100.00 & 0.00 & 100.00 & 0.00 & 100.00 \\
\hline Rizolex & & 13.33 & 82.61 & 7.17 & 77.55 & 15.00 & 79.54 & 8.09 & 74.30 \\
\hline Control & & 76.67 & 0.00 & 34.66 & 0.00 & 73.33 & 0.00 & 31.47 & 0.00 \\
\hline LSD at $5 \%$ & & 12.78 & & 2.16 & & 14.89 & & 2.23 & \\
\hline
\end{tabular}

$\mathrm{DI}=\%$ Disease incidence; DS =\% Disease severity; Ef. = \%Efficacy; Control = infected with $R$. solani and un-treated

\section{Effect of tested nanoparticles on activities of defense related}

Data in Table (4) illustrate that all tested nanoparticle materials displayed positive effect in increasing enzymes activity. The highest increase in the activity of polyphenol oxidase was observed in potato plants treated with tri-calcium phosphate in both leaves and tubers compering to control. In this respect, tricalcium phosphate had strong effect in increasing peroxidase and catalase activity in potato leaves and tubers followed by silicon dioxide and copper oxide. while the highest activity of chitinase was obtained in 
potato leaves treated with copper oxide and in potato tubers treated with silicon dioxide. Although, plants treated with Rizolex showed a high increase in polyphenol oxidase, catalase, chitinase activity, meanwhile peroxidase activity was higher in potato leaves treated with tested nanoparticles materials than plants treated with Rizolex. It has been reported that silicon stimulates the activity of these enzymes during plant-pathogen interactions (Fauteux et al., 2005; Datnoff et al., 2007; Van et al., 2013). In this respect, several studies have reported the role of silicon in stimulating resistance by activating defense-related enzyme activities such as chitinase, peroxidase, polyphenol oxidase, b-1, 3glucanase, phenylalanine ammonia-lyase, uperoxide dismutase, ascorbate peroxidase, glutathione reductase, catalase, lipoxygenase, and glucanase. Phenylalanine ammonialyase involved in the synthesis of plant secondary antimicrobial substances and it is essential for plant disease resistance responses (Waewthongrak et al., 2015). The peroxidase, catalase, superoxide dismutase activities of Lemna minor increased with the increase in $\mathrm{CuO}$ NPs, bulk $\mathrm{CuO}$, and $2 \times \mathrm{Cu} 2+$ concentration released from CuO NPs (Song et al. 2016).

Table 4. Effect of some tested nanoparticls materials on activities of defense in potato plants and tubers cv. spunta

\begin{tabular}{lcccccccc}
\hline \multirow{2}{*}{ Treatment } & \multicolumn{9}{c}{ Enzyme activity } \\
\cline { 2 - 9 } & \multicolumn{2}{c}{ polyphenol oxidase } & \multicolumn{2}{c}{ Peroxidase } & \multicolumn{2}{c}{ Catalase } & \multicolumn{2}{c}{ Chitinase } \\
\cline { 2 - 9 } & leaves & Tubers & Leaves & Tubers & Leaves & tubers & leaves & Tubers \\
\hline Copper oxide & 0.33 & 0.23 & 2.88 & 1.98 & 1.76 & 1.47 & 6.22 & 4.21 \\
Tri-calcium phosphate & 0.49 & 0.43 & 3.85 & 3.27 & 1.88 & 1.63 & 4.65 & 3.60 \\
Silicon dioxide & 0.41 & 0.38 & 3.61 & 2.31 & 1.67 & 1.54 & 5.34 & 4.28 \\
Rizolex & 0.97 & 0.71 & 2.65 & 2.48 & 1.89 & 1.82 & 9.33 & 7.33 \\
\hline Control & 0.190 & 0.189 & 0.5 & 0.7 & 1.04 & 1.12 & 3.78 & 2.54 \\
\hline
\end{tabular}

\section{References}

Abd El-Aziz, R.M.A.; Mahmoud, M.A.; Al-Othman, R.M.; Abedel-Sattar, M.A.; El-Sherir, M. E. and El-Mazouky, H. (2013): Differential interaction between isolates of Rhizoctonia solani AG-3 and potatoes cultivars. African Journal of Microbiology Research, 2(12): 1045-1054.

Allan, A.I. and Hollis, J.P. (1972): Sulfide inhibition of Oxidases In rice roots. Phytopathology, 62: 634636.

Amin, H. Basma (2013): Studies on antifungal agents extracted from some desert and cultivated plants. Ph.D. Thesis Botany and Microbiology Department, Al-Azhar University.

Banik, S. and Perez-de-luque, A. (2017): In vitro effect of copper nanoparticles on plant pathogens beneficial microbes and crops plants. Spanish Journal of Agricultural Reaserch, 15(2) e1005, 15 pages.

Beveridge, T.J. and R. Murray, G.E. (1980) Sites of metal deposition in the cell wall of Bacillus subtilis. J. Bacteriol., 141:876-877.

Bramhanwade, K.; Shende, S.; Bonde, S.; Gade, A. and M. Rai (2015): Fungicidal activity of $\mathrm{Cu}$ nanoparticles against Fusarium causing crop diseases. Environmental Chemistry Letters, DOI 10.1007/s10311-015-0543-1.

Brecht, M.O.; Datnoff, L.E.; Kucharek, T.A. and Nagata R.T. (2004): Influence of silicon and chlorothalonil on the suppression of gray leaf spot and increase plant growth in St. Augustine grass. Plant Disease, 88: 338-344.

Capeletti, L.B.; De Oliveria, L.F.; De Almeida, G.K.; De Oliveira, J.F.A.; Saito A. and Kobarg, J. (2014): Tailored silica-antibiotic nanoparticles: overcoming bacterial resistance with low cytotoxicity. Langmuir, 30:7456-64, http://pubs.acs.org/dio/abs/1021/a4046435.

Caiab, Y. and Tang, R. (2008): Calcium phosphate nanoparticles in biomineralization and biomaterials, J. Mater. Chem., 18: 3775-3787

Chang, Y.N.; Zhang, M.; Xia, L.; Zhang, J. and Xing, G. (2012): The toxic effects and mechanisms of $\mathrm{CuO}$ and $\mathrm{ZnO}$ nanoparticles. Materials, 5:2850- 2871.

Cioffi, N.; Torsi, L.; Ditaranto, N.; Tantillo, G.; Ghibelli, L.; Sabbatini, L.; Bleve-Zacheo, T.; D’Alessio, M.; Zambonin, P.G. and Traversa, E. (2005): Copper nanoparticle/polymer composites with antifungal and bacteriostatic properties. Chem. Mater 17: 5255-5262. https://doi.org/10.1021/cm0505244

Datnoff, L.E.; Elmer, W.H. and Huber; D.M. (2007): Mineral Nutrition and Plant Disease. St. Paul, MN: The American Phytopathological Society, https://trove.nla.gov.au/version/46560974.

Dorrance, A.; Kleinhenz, D.M.; McClure, A.S. and Tuttle, N. (2003): Temperature, mointure and seed treatment effect on Rhizoctonia solani root rot of soybeen. Plant disease, 87(5).533-538.

Fauteux, F.; Remus-Borel, W.; Menzies, J.G. and Belanger, R.R. (2005): Silicon and plant disease resistance against pathogenic fungi. 
FEMSMicrobiol. Lett. 249, 1-6. doi: 10.1016/j.femsle.2005.06.034.

Gill, S.; Fouts, D. E.; Archer, G.L.; Mongodin, E.F.; Deboy, R.T. and Ravel, J. (2005) Insights on evolution of virulence and resistance from the complete genome analysis of an early methicillinresistant Staphylococcus aureus strain and a biofilmproducing methicillin-resistant Staphylococcus epidermidis strain. J. Bacteriol., 187:2426-38.

Gogoi, R.; Dureja, P.; and Singh, P.K. (2009): Nanoformulations a safer and effective option for agrochemicals. Indian Farming, 59(8):7-12.

Gopalakrishnan, K.; Ramesh, C.; Ragunathan, V. and Thamilselvan, M. (2012): Antibacterial activity of $\mathrm{Cu} 2 \mathrm{O}$ nanoparticles on $E$. coli synthesized from tridax procumbens leaf extract and surface coating with polyaniline. Dig J. Nanomater Bio., 7(2):833-839.

Hadi, M.R. and Balali, G.R. (2010): The Effect of Salicylic Acid on the Reduction of Rizoctonia solani Damage in the tubers of Marfona Potato Cultivar. Am-Euras. J. Agric. \& Environ. Sci., 7 (4): 492-496.

Hamideldin, N. and Hussien, O.S. (2013): Morphological, Physiological and Molecular Changes in Solanum tuberosum L. in Response to Pre-Sowing Tuber Irradiation by Gamma Rays. American Journal of food science and Technology, 1: 36-41.

Jia, B.; Mei, Y.; Cheng, L.; Zhou, J. and Zhang, L. (2012): Preparation of copper nanoparticles coated cellulose films with antibacterial properties through one-step reduction. ACS Appl Mater Interfaces, 4: 2897-2902. https://doi.org/10.1021/am3007609.

Kaguongo, W.P.; Gildemacher, P.; Demo, P.; Wagoire, W.; Kinyae, P.; Andrade, J.; Forbes, G.; Fuglie, K. and Thiele, G. (2008): Framer Practices and Adoption of Improved Potato Varieties in Kenya and Uganda. International Potato Center (CIP), Lima. SOCIAL Sciences Working Paper, 5: 85 p.

Kanhed, P.; Birla, S.; Gaikwad, S.; Gade, A.; Seabra, B. A.; Rubilar, O.; Durcn, N. and Pai, M. (2014): In vitro antifungal efficacy of copper nanoparticles against selected crops pathogenic fungi. Materials letters, 115:13-17.

Kato, M., and Shimizu, S. (1987): Chlorophyll metabolism in higher plants. VII.Chlorophyll degradation in senescing tobacco leaves; phenolicdependent peroxidative degradation. Can. J. Bot., 65: 729-735.

Kim, H.J.; Park, H.J. and Choi, S.H. (2011): Antimicrobial action effect and stability of nanosized silica hybrid Ag complex. J Nanosci Nanotechnol., 11(7):5781-7.
Liedl, B.E.; Kosier, T. and Sesbarought S.L. (1987): HPLC isolation and nutritional value of a major potato tuber protein. Am. Potato J. 11: 77-8

Matny N. O. and Al-Jarrh (2014): Induce resistance against black scurf disease caused by Rhizoctonia solani in potato (Solanum tuberosum) . Journal of Experimental biology and Agricultural science. 2(3):337:342.

Matta, A.I. and Dimond, F.A. (1963): Symptoms of Fusarium wilt in relation to quantity of fungus and enzyme activity in tomato stems. Phytopathol., 53: 574-578.

Miller, G.L. (1959): Use of dinitrosalicylicacid reagent for determination of reducing sugar. Analytical Chem., 31: 426-428.

Mahmoud, E.Y.; Ibrahim, M.M.; and Essa, T.A.A. (2013): Efficacy of plant essential oil in controlling dampping-off and root rots disease $s$ of peanut as fungicides alternative. Journal of Applied Sciences Research, 9(3): 1612-1622.

Park, H.J.S.H.; Kim, H.J.; Kim, S. and Choi, H. (2006): A new composition of nanosized silica-silver for control of various plant diseases. Plant Pathol. J., 22: 295-302.

Patil, V.; Patil, U.V.; Singh, R. and Singh, B. (2016).: Genetic Engineering for Enhanced Nutritional Quality in Potato - a review . Potato Journal 43(1):1-21.

Pérez-de-Luque, A. and Hermosín, C. (2010): Nanotechnology and its use in agriculture. In: Bio-nanotechnology: a revolution in food, biomedical and health sciences; Bagchi D, Bagchi M, Moriyama H, Shahidi F (eds.). pp: 383-398. Blackwell Publ Ltd.,

Prachi, K.A.; Sonal, B.A.; Swapnil G.A.; Aniket G.A.; Amedea B.S.; Olga, R.; Nelson D. and Mahendra, R. (2014): In vitro antifungal efficacy of copper nanoparticles against selected crop pathogenic fungi. Materials Letters.115:13-17.

Poczai, P.; Cernák, I.; Gorji, A.M.; Nagy, S.; Taller, J. and Polgár, Z. (2010): Development of Intron Targeting (IT) Markers for Potato and CrossSpecies Amplification in Solanum nigrum (Solanaceae). American Journal of Botany, 97, e142-e145. http://intl.amjbot.org/ http://dx.doi.org/10.3732/ajb.1000360.

Ramyadevi, J.; Jeyasubramanian K.; Marikani, A.; Rajakumar, G. and Abdul Rahuman, A. (2012): Synthesis and antimicrobial activity of copper nanoparticales. Materials letter, 71: 114-116.

Ren, G.; Hu, D.; Cheng, E.W.C.; Vargas-Reus, M.A.; Reip, P. and Allaker, R.P. (2009): Characterization of copper oxide nanoparticles for antimicrobial applications. Int. J. Antimicrob. Agents, 33:587-590. 
Rezaei-Zarchi, S.; Javed, A.; Ghani, M. J.; Soufian, S.; Firouzabadi, F. B. and Moghaddam A. B. (2015): Comparative study of antimicrobial activities of $\mathrm{TiO} 2$ and $\mathrm{CdO}$ nanoparticles against the pathogenic strain of Escherichia coli. Iran J. Pathol., 5(2):83-9.

Rubayet, M. T.; Bhuiyan M.K.A.; Jannat R.; Masum M. M. I. and Hossain, M. M. (2018): Effect of biofumigation and soil solarization on stem canker and black scurf diseases of potato (Solanum tuberosum L.) caused by Rhizoctonia solani isolate PR2. Advances in Agricultural Science., 6 (03): 33-48.

Schrand, A.M.; Rahman, M. F.; Hussain S. M.; Schlager J. J.; Smith D. A. and A. F. Syed (2010): Metalbased nanoparticles and their toxicity assessment. WIREs Nanomed Nanobiotechnol., 2:554-568.

Sirirat, S.; Rungprom, W. and Sawatdikarn, S. (2009): Antifungal activity of essential oils derived from some medicinal plants against grey mould (Botrytis cinerea) As. J. Food Ag-Ind. 2009, Special Issue, S229-S233.

Sneh, B.; Burpee, L. and Ogoshi, A. (1991): Identification of Rhizoctonia species. The APS Press, St. Paul, MN, USA, 133 pp.

Sneyers, G. (2010) Potato and Commodity Development. In: Cromme, N., Prakash, A.B., Lutaladio, N.B. and Ezeta, F., Eds., Strengthening Potato Value Chains: Technical and Policy Options for Developing Countries, The Food and Agriculture Organization of the United Nations and the Common Fund for Commodities, Rome, 12-13.

Song, G.; Wenhua, H.; Yuan, G.; Yan, W.; Lin L.; Zhang, Z.; Qiang, N.; Rulin, M.; Lati M. and Wang, H. (2016): Effects of $\mathrm{CuO}$ nanoparticles on Lemna Minor. Bot. Stud., 57:3.
Suriyaprabha, R.; Karunakaran, G.; Kavitha K.; Yuvakkuma, R.; Rajendran, V. and Kannan, N. (2014): Application of silica nanoparticles in maize to enhance fungal resistance. IET Nanobiotechnol. 8(3):133-7.

Van, B.J.; De Vleesschauwer, D. and Hofte, M. (2013): Towards establishing broadspectrum disease resistance in plants: silicon leads the way. J. Exp. Bot. 64: 1281-1293. doi: 10.1093/jxb/ers329

Waewthongrak, W.; Pisuchpen, S.; and Leelasuphakul W., (2015). Effect of Bacillus subtilis and chitosan applications on green mold (Penicillium digitatum Sacc.) decay in citrus fruit. Postharvest Biol. Technol., 99: 44-49. doi: 10.1016/j. postharvbio.2014.07-016

Wilson, S.P.; Ahvenniemi, M.P.; Lehtonen, J.M.; Kukkonen, M.; Rita, H. and Valkonen, P.T.J., (2008): Biological and chemical control and their combined use to control different stages of the Rhizoctonia disease complex on potato through the growing season. Ann. Appl. Biol.; 153: 307320.

Workman, D. (2018): Potatoes Exports by Country. http://www. Worldstopexports.com/ potatoesexports-by-country/.

Yuvakkumar, R.; Elango, V.; Rajendran, V.; Kannan, N. and Prabu, P. (2011) Int. J. Green Nanotechnol., 3: 180-190.

Zachow, C.; Grosch, R. and Berg, G. (2011): Impact of biotic and a-biotic prameters on structure and function of microbial communities living on sclerotia of the soil-born pathogenic fungus Rhizoctonia solani. Appl soil Ecol. 48(2):193200. 


\section{كفاءة أكسيد النحاس وفوسفات الكالسيوم الثلاثيه وفوق أكسيد السليكون بمركبات النانونيه في مكافحة مرض القشرة السوداء علي البطاطس}

$$
\begin{aligned}
& \text { إيمان سعيد عبد البافي الثيوي², فتحي جاد محمد', فاتن محمود عبداللطيف1, محمد السيد حافظ , عارف سليمان منصور2 } 2
\end{aligned}
$$

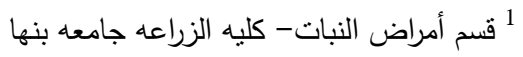

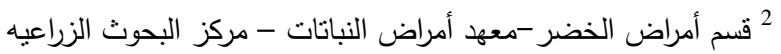

تهدفت الدراسة إلي مقاومة مرض القشرة السوداء في البطاطس والناتج عن فطر مhizoctonia solani والذي يعد من اخطر الامراض الفطريه التي

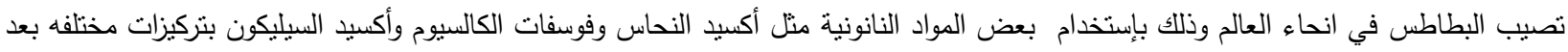

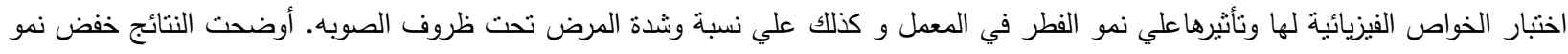

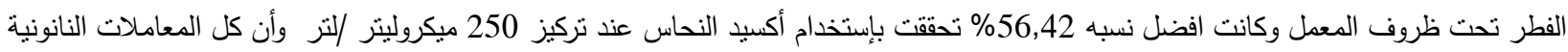

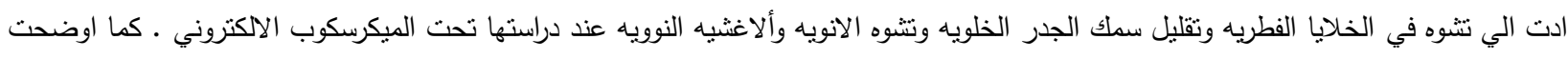

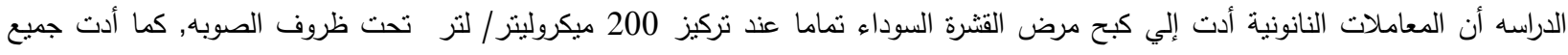
المعاملات النانونية الي زياده في أنشطه الانزيمات المرتبطه بالدفاع النشط في النبات مما يزيد من أستخدمها في مكافحه المرض. 